\title{
Thyroid Cancer pNO TNM Finding v6 and v7
}

National Cancer Institute

\section{Source}

National Cancer Institute. Thyroid Cancer pNO TNM Finding v6 and v7. NCI Thesaurus.

Code C60871.

Thyroid cancer with no regional lymph node metastasis. (from AJCC 6th and 7th Eds.) 